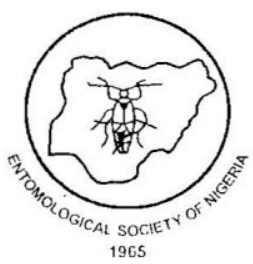

\title{
Sexual Variations in Nutritive Value of Adult Variegated Grasshopper, Zonocerus variegatus (Linnaeus, 1758) (Orthoptera: Pyrgomorphidae)
}

\author{
ADEMOLU, K.O.*, SALAMI, S. E., IYEH, C.I., ALADESIDA, A. A., \\ JODA, A.O.' AND IDOWU, A. B. \\ Department of Pure and Applied Zoology, Federal University of Agriculture, \\ Abeokuta, Ogun State, Nigeria.
}

Nig. J. Entomol. 33: 17-21 (2017)

\begin{abstract}
The act of eating insects (entomophagy) has been on the increase due to their medicinal and nutritional importance. This study examined the sexual differences in the nutritive value of adult variegated grasshopper, Zonocerus variegatus. The proximate composition (crude protein, carbohydrate, fat, crude fibre. and ash), mineral profile $\left(\mathrm{Na}^{-}, \mathrm{Ca}^{2+}, \mathrm{Mg}^{2+}\right.$, and $\mathrm{Fe}^{2+}$ ), vitamin ( $A, B_{1}, B_{2}$, and $C$ ), anti-nutrient (alkaloid. antraquinone, flavonoid, saponin, and tannin) and heavy metal contents $\left(\mathrm{Cd}^{2+}, \mathrm{Cu}^{2-}, \mathrm{Ni}^{2+}, \mathrm{Pb}^{2+}\right.$, and $\mathrm{Zn}^{2+}$, of 5-day old adult male and female Zonocerus were analysed by standard methods. Female $Z$. variegatus had significantly higher $\left(\mathrm{t}_{u}=0.05\right)$ crude protein, ash, fibre and carbohydrate than the male. Anti-nutrients and heavy metal contents of the adult Zonocerus varied from $0.210-8.82 \%$ and $0.113-1.264 \mathrm{mg} / 100 \mathrm{~g}$, respectively, with the female having higher values. Adult female Z. variegatus is thus more nutritious than the male.
\end{abstract}

Keywords: Zonocerus variegatus, nutrients, sexual differences, minerals, heavy metals.

\section{INTRODUCTION}

The eating of insects by humans (entomophagy) is on the increase as knowledge on their nutritional and medicinal benefits becomes more global (Banjo et al., 2006). Few years back, Idowu and Modder (1996) reported the practice of eating variegated grasshopper, Zonocerus variegatus, by the people of Ikare, Owo and Oka-Akoko of Ondo State. Nigeria. Insects are consumed at different life stages including eggs, larvae, pupae or adults and their consumption is highly influenced by cultural, social, and religious factors (Jongema, 2017).

Insects commonly consumed include ants, bees, beetles, cicadas, com borer, crickets, flies,

*Corresponding author:

E-mail: kennyademolu(ci yahoo.com grasshoppers and grubs. Insect proteins possess nutritional advantages in total protein levels and essential amino acid profiles over plant proteins such as cereals, beans or soybean (Rumpold and Schluter, 2014). Insects also have higher levels of quality proteins $(50-85 \%)$ and significant amounts of other nutrients like lipids, vitamins, and minerals (Bukkens, 2005).

The variegated grasshopper is a polyphagous insect found in the forest and savanna zones of Central and West Africa (Chiffaud and Nestre, 1990). It consumes both food and cash crops in the tropics, namely, banana. cassava, cocoa, citrus, cowpea and yam (Toye, 1982).

The life cycle of $Z$. variegatus is usually a calendar year with two populations: a dry season population (November-March) and a wet season population(April-October)(Toye, 1982).

However, the average life span of $Z$. variegatus from nymph to adult is $9-10$ months 
(Anya, 1973).A breakdown of the life cycle showed that nymphal derelopmental stages spread over $111.1 \pm 0.02$ days, while the life spans of male and female adults were

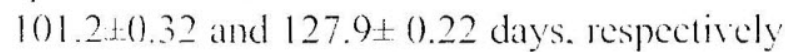
(Ademolu et al.. 2013). Morphometric analyses showed a progressive increase in size of all the body parts of Z.rariegatus during post embryonic development. Sexual dimorphism is a common phenomenon in insects; it arises from natural selection of each gender. Muse (2003) observed that female $Z$. variegatus lived longer than their male congeners either in group or isolation. Ademolu (2013) similarly reported sexual dimorphism in the somatic tissue responses of Zonocerns to copulation. Based on their different mating behaviour and tissue (femoral muscles, haemolymph, and antennae) composition, it is hypothesized that there will be sexual differences in the nutritive value of $Z$. variegatus. This study determined the sexual differences in the nutritive value of $Z$. variegatus.

\section{MATERIALSAND METHODS}

\section{Collection and Maintenance of Insects}

Nymphs in the penultimate (6th) instar stage of development of $Z$. variegatus were collected with a sweep net from uncultivated farm land opposite the gate of Federal University of Agriculture, Abeokuta, Nigeria (FUNAAB), brought to the insectary in the Department of Pure and Applied Zoology, FUNAAB, and sorted into sexes. The insects were maintained on Manihot esculenta (cassara) leaves in a wire mesh cage $(30 \times 30 \times 45 \mathrm{~cm}$ ) (Idowu et al., 2004). Five days after adult emergence. Zonocerus samples (24.35+0.33g) were taken out and asphyxiated in a deep freezer at $-25^{\circ} \mathrm{C}$ for 15 minutes beforebeingused forchemical analysis.

\section{ChemicalAnalyses}

The proximate composition (crude protein, carbohydrate. fat. crude fibre, and ash), vitamin (A.B, B. and C) anti-nutrients (alkaloid, antracpuinone. Havonoid, saponin, and tammin), and heary metal $\left(\mathrm{Cd}^{2}, \mathrm{Cu}^{2}, \mathrm{Ni}^{2}, \mathrm{~Pb}^{2}\right.$, and $\left.\mathrm{Zn}^{2},\right)$ contents of 5 -day old adult $Z$. rarlegatus males and females were determined by methods of A.O.A.C. (1990). The minerals $\mathrm{Ca}^{2}+. \mathrm{Mg}^{2-} \cdot \mathrm{Fe}^{2-}$ were analysed by atomic absorption spectrophotometry while $\mathrm{Na}$ was determined with a Corning 410 Flame Photometer. All the chemical analyses were carried out in triplicates.

\section{StatisticalAnalyses}

Data collected were subjected to student's t-test to detect significance of differences $\left(\mathrm{t}_{\alpha}=0.05\right)$ between sexes.

\section{RESULTS}

The proximate composition of the male and female adult $Z$. variegatus is shown in Table 1 . The female had significantly higher crude protein, ash, fibre, and carbohydrate than the male but both sexes had statistically comparable fat content $(1.00-1.18 \mathrm{~g} / 100 \mathrm{~g})$. Excluding $\mathrm{B}_{2}$, other vitamins were numerically higher in females than in males but the difrences were due to random variation $\left(t_{u}>0.05\right)$. Th range of values for vitamin Cwas higher than those forother itamins (Table2). In decreasing order of magnitude, the mineral content of adult $Z$. variegatus was $\mathrm{Ca}^{2}>\mathrm{Mg}^{2}>$ $\mathrm{Na}>\mathrm{Fe}^{2}$. Statistically significant sexual differences were detected with the male having higher content of $\mathrm{Ca}^{2}$ and $\mathrm{Mg}{ }^{2}$ but low reontents of $\mathrm{Na}$ and $\mathrm{Fe}$ (Table 3). Both sexes contained measurable lerels of alkaloid. antraquinome, flar onoid. sapenin. and tannin. With the exeeption of saponin. the contents were significantly higher in the female (Table 4 ).

Table 1: Proximate composition (g/100g)of adult male and female Zonocerus variegatus

\begin{tabular}{|c|c|c|c|c|c|c|}
\hline Six & Dry Matler & (rukle Protcin & Cathohydratc & Fit & (rucke tibce & Ash \\
\hline Mals & $33.040+0.04$ & $1+.9\left(1010.03^{1=}\right.$ & $15.1+(0)+0.014^{6}$ & $1.0000: 0.10$ & $1.0 .3010 .0133^{10}$ & $0.907 \pm 0.01^{\mathrm{h}}$ \\
\hline Ficmale & $38.350+0.05^{0}$ & $\mid 7.2 x\left(0+\left.0.0\right|^{1}\right.$ & $17.73010 .033^{3}$ & $1.1501:(1.011$ & $1.1+(1)+1) .04$ & $1.0 .50: 00.00^{2.1}$ \\
\hline
\end{tabular}


Table 2: Comparison of vitamin contents $(\mathrm{mg} / 100 \mathrm{~g})$ of adult male and female Zonocerus varicgatus

\begin{tabular}{lllll}
\hline Sex & Vitamin A & Vitamin $B_{1}$ & Vitamin $B_{2}$ & Vitamin C \\
Male & $6.920 \pm 0.02$ & $0.104=0.00$ & $0.066 \pm 0.00$ & $8.140 \pm 0.04$ \\
Female & $6.950 \pm 0.03$ & $0.089=0.00$ & $0.062 \pm 0.00$ & $8.220 \pm 0.02$ \\
\hline
\end{tabular}

Table 3: Mineral composition $(\mathbf{m g} / \mathbf{1 0 0 g})$ of adult male and female Zonocerus variegatus

\begin{tabular}{lllll} 
Sex & $\mathrm{Na}^{+}$ & $\mathrm{Ca}^{2+}$ & $\mathrm{Mg}^{2+}$ & $\mathrm{Fe}^{2+}$ \\
Male & $21.611 \pm 0.00^{\mathrm{b}}$ & $78.301 \pm 0.00^{\mathrm{a}}$ & $10.364 \pm 0.00^{\mathrm{a}}$ & $2.169 \pm 0.00^{\mathrm{b}}$ \\
Female & $21.684 \pm 0.00^{\mathrm{a}}$ & $72.458 \pm 0.00^{\mathrm{h}}$ & $9.873 \pm 0.00^{\mathrm{b}}$ & $2.361 \pm 0.00^{\mathrm{a}}$ \\
\hline
\end{tabular}

* Mcan values ( \pm s.e.) in a column having different superseript are significantly different ( $\alpha=0.05$ ).

Table 4: Anti-nutrient composition (\%) of adult male and female Zonocerus variegatus

\begin{tabular}{llllll}
\hline Sex & Tannin & Saponin & Alkaloid & Flavonoid & Antraquinone \\
\hline Male & $2.410 \pm 0.01^{\mathrm{b}}$ & $6.740 \pm 0.04^{\mathrm{a}}$ & $1.770 \pm 0.02^{\mathrm{b}}$ & $7.670 \pm 0.02^{\mathrm{b}}$ & $0.210 \pm 0.01^{\mathrm{b}}$ \\
Female & $2.510 \pm 0.01^{\mathrm{a}}$ & $6.110 \pm 0.01^{\mathrm{b}}$ & $1.820 \pm 0.02^{\mathrm{a}}$ & $8.820 \pm 0.02^{\mathrm{a}}$ & $0.280 \pm 0.01^{\mathrm{a}}$ \\
\hline
\end{tabular}

* Mean values ( \pm s.e.) in the same column having different superseript are significantly different $\left(\mathrm{t}_{\mathrm{n}}=0.05\right)$.

Table 5: Heavy metal composition $(\mathbf{m g} / \mathbf{1 0 0 g})$ of adult male and female Zonocerus variegatus

\begin{tabular}{llllll}
\hline Sex & $\mathrm{Pb}^{2+}$ & $\mathrm{Zn}^{2+}$ & $\mathrm{Cu}^{2+}$ & $\mathrm{Cd}^{2+}$ & $\mathrm{Ni}^{2+}$ \\
\hline Male & $1.006 \pm 0.00^{\mathrm{b}}$ & $1.071 \pm 0.00^{\mathrm{b}}$ & $0.861 \pm 0.00^{\mathrm{b}}$ & $0.286 \pm 0.00^{\mathrm{b}}$ & $0.113 \pm 0.00^{\mathrm{b}}$ \\
Female & $1.104 \pm 0.00^{\mathrm{a}}$ & $1.264 \pm 0.00^{\mathrm{a}}$ & $0.884 \pm 0.00^{\mathrm{a}}$ & $0.341 \pm 0.00^{\mathrm{a}}$ & $0.124 \pm 0.00^{\mathrm{a}}$ \\
\hline
\end{tabular}

*Mean values ( \pm s.e. $)$ in the same column having different superscript are significantly different $\left(\mathrm{t}_{\mathrm{u}}=0.05\right)$.

Table 5 compares heavy metal content of adult male and female $Z$. variegatus. The content of $\mathrm{Cu}^{2+}, \mathrm{Pb}^{2+}, \mathrm{Ni}^{2+}, \mathrm{Zn}^{2+}$, and $\mathrm{Cd}^{2+}$ in females were 1.03-, 1.10-, 1.10-, 1.18-, and 1.19-fold greater $\left(\mathrm{t}_{a}>0.05\right)$ than in the males (Table 5).

\section{DISCUSSION}

Zonocerus variegatus had always been an item in the diet of the Yorubas in southwestern Nigeria (Banjo et al., 2006; Idowu and Modder, 1996). This fact is probably not unconnected to the high nutritional value of this species. Alegbeleye et al. (2011) incorporated varying levels of Zonocertus adults in the diets of Clarias gariepinus to replace fish meal and concluded that the insect could replace up to $25 \%$ of the fishmeal without adverse effect on fish grow th and nutrient utilization.

Adult female $Z$. variegatus had significantly higher protein, carbohydrate, and ash contents than the male. Female insect generally invest more in reproductive process than males, mobilizing resources and nutrients in the early somatic stage for this energy demanding process (Ademolu et al., 2011). Chapman (1990) had shown that protein is important and highly needed during egg maturation and vitellogenesis.

The crude fat content was in the range $0.907-1.05$ $\mathrm{g} / 100 \mathrm{~g}$. This low fat content makes $Z$. variegatus an ideal diet for Nigerians, particularly those with heart-related ailments.

Vitamins $\mathrm{A}, \mathrm{B}_{1}, \mathrm{~B}_{2}$, and $\mathrm{C}$ were detected at higher levels in the adults than reported for the early nymphal instars $\left(1^{\text {st }}-3^{\text {rd }}\right)$ by Ademolu et al. (2010). The numerically higher values in females also relate to greater investment in reproductive process. The high value of $\mathrm{Ca}^{2}$, in the adult female in particular, is expected given that the mineral is an important constituent of egg shell and chorion and an essential requirement in embryo development (Kaneuchi et al., 2015). The anti-nutrient and heavy metal content of both sexes were lower than World Health Organization's critical limits (WHO, 2009) thus making $Z$. variegatus safe for consumption. In general, the higher values of nutrients in the adult female $Z$. varicgatus could be the result of higher food consumption by this sex (Ademolu etal.,2016). 


\section{REFERENCES}

Ademolu, K. O. (2013). Sexual dimorphism in somatic tissues' response to copulation in adult Zonocerms renriegatus (L). Nigerian Journal of Entomologi; 30:164-169.

Ademolu, K.O., Idowu, A.B. and Oke, O.A. (2011). Impact of reproduction activities on the tissues of Zonocerus variegatus (Orthoptera: Pygomorphidae). Florida Entomologist, 94 (4):993-997.

Ademolu, K.O. Idowu, A.B. and Oke, O.A. (2013). Life cycle and morphometric studies of variegated grasshopper Zonocerus variegatus (Linnaeus, 1758). Munis Entomology and Zoology, 8(1):375-381.

Ademolu, K. O. Idowu, A. B. and Olatunde, G.O. (2010). Nutritive value assessment of variegated grasshopper, Zonocerus variegatus (Orthoptera: Pyrgomorphidae) during post embryonic development. African Entomology; 18(2):360-364.

Ademolu, K.O. Olusunmade, E. Adelabu, B. and Idowu, A.B. (2016). Sexual differences in destructive capability and midgut enzymes activities in adult variegated grasshopper, Zonocerus variegatus Linnaeus, 1758) (Orthoptera: Pyrgomorphidae). Polish Journal of Entomologi; 86:453-460.

Alegbeleye, W. O., Obasa, S. O., Olude, O. O., Otubu, K., and Jimoh, W. (2011). Preliminary evaluation of the nutritive value of variegated grasshopper (Zonocerus variegatus L.) for African catfish, Clarias garicpinus (Burchell,1822) fingerlings. Ayucuculture Resecurch, 43(3):412-420.

Anya, A.O. (1973). Ecology of the variegated grasshopper; Zonocernsicuricgatus (Orthoptera: Acridoidea, Pyrgomorphidae) on the Nsukka plateau, Nigeria. Entomologia Experimentalise Applicata, 16:64-76.

AOAC (1990). Official Methods of Analysis of the Association of Official Analytical Chemists (Hormitz, W.ed.). 13"'ed.. Washington. 1142pp.

Banjo, O.Y., Lawal, O.A. and Sangonuga, E.O.(2006). The nutritional value of fourteen species of edible insects in southwestern western Nigeria. African Jomnal of
Biotechnolog! 5(3): 298-201.

Bukkens, S. G. F. (2005). Insects in the human diet: Nutritional aspects. In: Ecological Implications of Minilivestock: Role of Rodents. Frogs, Sinuils. and Insects for Sustainable Derelopment (Paoletti, M. G.ed.), pp. 545--577. Science Publishers, New Hampshire, USA.

Chapman, R. F. (1990). The Insects Structure and Function. The English Language Book Society and Hodder and Stoughton, Great Britain, 986pp.

Chiffaud, J. and Mestre, J. (1990). Le Croquet Puant Zonocerus variegatus (Linne, 1758) CIRAD-PRIFAS, Paris . 140pp.

Idowu, A. B. and Modder, W. W. D. (1996). Possible control of the stinking grasshopper, Zonocerus variegatus (L.) (Orthoptera: Pyrgomorphidae) in Ondo State through human consumption. The Nigerian Field, 61:7-14.

Idowu, M. A., Idowu, A. B. and Faseki, M. F. (2004). Nutrient composition and processing of variegated grasshopper Zonocerus variegatus (L) for human consumption. Nigerian Journal of Entomologi; 21:65-70.

Jongema, Y. (2017). List of edible insect species of the world. Retrieved from: http://www.ent.wur.nl/UK/ Edible+insects/Worldwide+species+list/ (Accessed 12 September, 2017).

Kaneuchi, T., Sartan, C. V., Horner, V. L., Buechner, N. A., Aigaki, T. and Wolfner, M. F. (2015). Calcium waves occur as Drosophila oocytes activate. Proceedings of National Academ of Sciences of United States of America, $112(3): 791-796$.

Muse, W.A. (2003). Effect of sex, age, starvation and feeding, isolation and crowding and oriposition on longevity of Zonocenzis variegatus (Orthoptera: Pygomorphidae). Journal of BiologicalResearchandBiotechnologi: 1(2):1120.

Rumpold, B. A. and Schlüter, O. K. (2014). Nutrient composition of insects and their potential application in fiend and feed in Europe. Food Chain, 4: 129-139.

Toye, S. A. (1982). Studies on the biology of 
the grasshopper pest Zonocerus varicgatus (L.) (Orthoptera: Pyrgomorphidae) in Nigeria. Inseret Science and its application $3(1): 1-7$.
WHO. (2009). Global prevalence of Vitamin A deficiency in populations at risk 1995-2005. WHO Global Database on Vitamin A Deficiency Nerlsletter; 4(2):5-6.8).

Ademolu. K.O.* Salami. S. E. , Iyeh. C.I. Aladesida, A. A.. Joda, A.O.' and Idowu. A. B.

Nigerian Journal of Entomology.

Published by the Entomological Society of Nigeria

Hu't:esn.org.ne

ISSN: $0331-0094$

Volume 33, 2017

p) 17-21

DOI: 10.36108/NJE/7102/33(0130) 